\title{
Invasive lionfish preying on critically endangered reef fish
}

\author{
Luiz A. Rocha ${ }^{1}$ - Claudia R. Rocha ${ }^{2}$ Carole C. Baldwin ${ }^{3}$ Lee A. Weigt ${ }^{3}$. \\ Melanie McField ${ }^{4}$
}

Received: 14 October 2014/ Accepted: 23 March 2015/Published online: 14 April 2015

(c) The Author(s) 2015. This article is published with open access at Springerlink.com

\begin{abstract}
Caribbean coral reef ecosystems are at the forefront of a global decline and are now facing a new threat: elimination of vulnerable species by the invasive lionfish (Pterois spp.). In addition to being threatened by habitat destruction and pollution, the critically endangered social wrasse (Halichoeres socialis), endemic to Belize's inner barrier reef, has a combination of biological traits (small size, schooling, and hovering behavior) that makes it a target for the invasive lionfish. Based on stomach content analyses, this small fish comprises almost half of the lionfish diet at the inner barrier reef in Belize. The combination of lionfish predation, limited range, and ongoing habitat destruction makes the social wrasse the most threatened coral reef fish in the world. Other species with small range and similar traits occur elsewhere in the Caribbean and face similar risks.
\end{abstract}

Keywords IUCN Red List - Halichoeres socialis . Caribbean $\cdot$ Coral reef decline

Communicated by Ecology Editor Dr. Alastair Harborne

Luiz A. Rocha

LRocha@calacademy.org

1 Section of Ichthyology, California Academy of Sciences, 55 Music Concourse Drive, San Francisco, CA 94118, USA

2 Center for Comparative Genomics, California Academy of Sciences, 55 Music Concourse Drive, San Francisco, CA 94118, USA

3 National Museum of Natural History, Smithsonian Institution, 10th and Constitution Ave, NW, Washington, DC 20560, USA

4 Healthy Reefs for Healthy People Initiative, Smithsonian Institution, 1755 Coney Dr, Belize City, Belize

\section{Introduction}

Coral reefs are among the most diverse and productive but also most threatened ecosystems on Earth, and decline is especially evident in the Caribbean, where threats include overfishing, pollution, sedimentation, climate change, and habitat destruction (Pandolfi et al. 2003). The invasive Pterois volitans and P. miles (two species that are almost identical and for simplicity referred to as "lionfish") were introduced in the tropical northwestern Atlantic in the mid1990s (Whitfield et al. 2002) and today are found along the Atlantic coast of the USA from Rhode Island to Florida, in the Bahamas and Gulf of Mexico, and throughout the Caribbean (Betancur-R et al. 2011). Invasive lionfish are 2-3 times more effective at removing small native fishes than native predators and therefore add to the growing list of threats to Caribbean reefs (Albins 2012). Lionfish seem to prefer prey that hover a few centimeters above the bottom, have elongated fusiform bodies, and range in size from 10 to $50 \mathrm{~mm}$ (Morris and Akins 2009; Valdez-Moreno et al. 2012; Côté et al. 2013; Green and Côté 2014).

The critically endangered social wrasse (Halichoeres socialis, family Labridae, Fig. 1a) fits the profile of lionfish preferred prey and is one of the only five coral reef fish species listed at the highest risk of extinction in the Red List of the International Union for Conservation of Nature (Rocha et al. 2010). The 2008 evaluation identified habitat degradation as the main threat to this species and did not mention lionfish, which were not a problem at the time (Rocha et al. 2010). The social wrasse is a planktivore with very specific habitat requirements and a narrow geographic range: It is found only on clear-water reefs around inshore mangrove islands of the Belize Barrier Reef World Heritage Site, especially around the Pelican Cayes (Lobel et al. 2009; Fig. 2). Lionfish are present in the entire depth range 

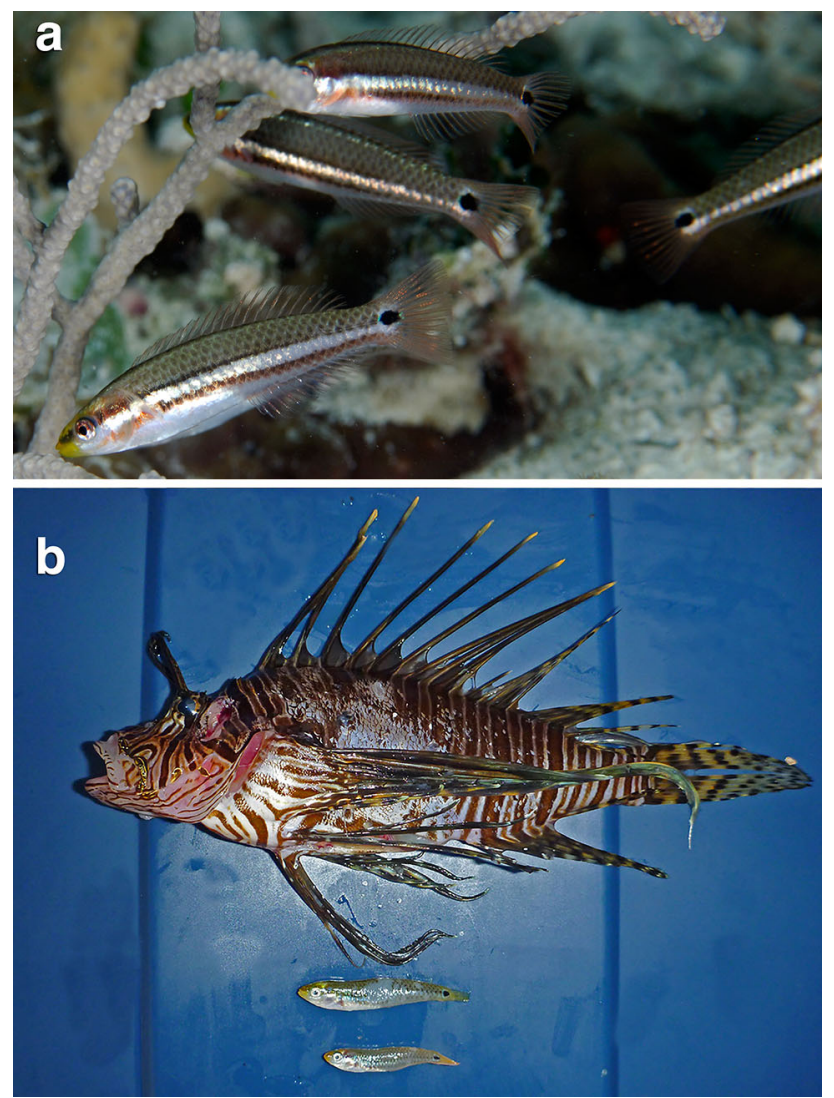

Fig. 1 a Critically endangered social wrasse, Halichoeres socialis, in reefs around mangrove islands of the Belize inner barrier reef. b Lionfish with two mature female social wrasses, Halichoeres socialis, recovered from its stomach

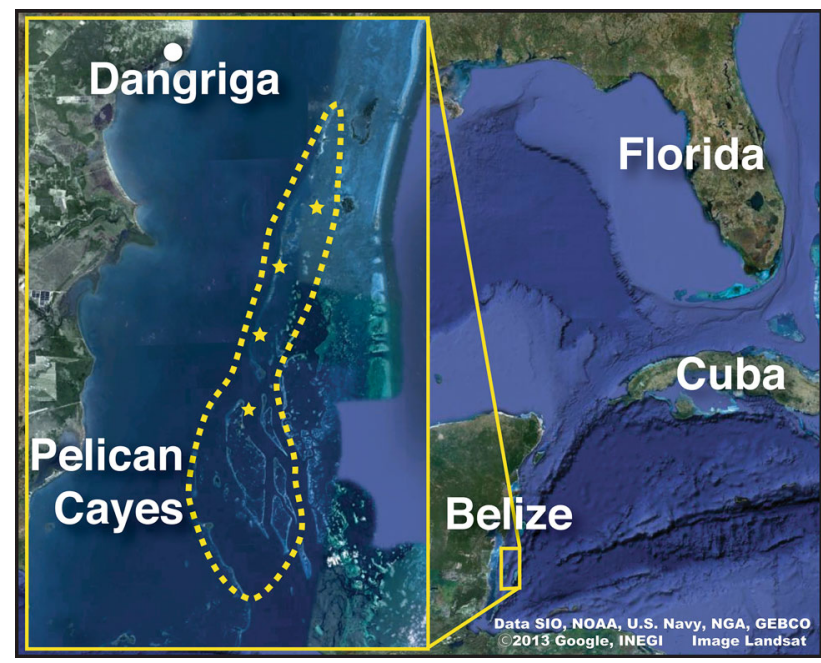

Fig. 2 Range of the social wrasse, Halichoeres socialis (dashed yellow line), and lionfish collecting sites (yellow stars). Map data from SIO, NOAA, USA Navy, NGA, and GEBCO downloaded from Google Earth
(1-9 m) and in all habitats (reefs, sea grass, and mangrove) where social wrasses are found, and a combination of impacts by invasive species and habitat degradation has been identified as the leading cause of extinction in fishes (Clavero and García-Berthou 2005). Aiming to determine whether lionfish represent an additional threat to the social wrasse, we conducted stomach content analyses to quantify the abundance and frequency of this critically endangered species in lionfish diet.

\section{Materials and methods}

In December 2012, we collected 68 lionfish specimens with sizes ranging from 5 to $35 \mathrm{~cm}$ total length by spearing while snorkeling or SCUBA diving within the habitat range of the social wrasse (reefs around inshore mangrove along the Belize barrier reef system; Fig. 2). Lionfish were placed on ice, and whole stomachs were removed at the Smithsonian field station in Carrie Bow Cay. Of the 68 stomachs, 24 were empty and were discarded. The remaining 44 were used in subsequent analyses.

Whenever possible, prey species identification was made through morphological analysis in the field. Items that were digested to a point where identification was not possible were preserved in $98 \%$ ethanol and taken to the Center for Comparative Genomics at the California Academy of Sciences for DNA sequencing. A portion of the cytochrome oxidase I mitochondrial DNA gene was sequenced for every sample. Polymerase chain reaction and sequencing conditions followed standard protocols described in detail elsewhere (Valdez-Moreno et al. 2012; Weigt et al. 2012; Côté et al. 2013). Sequencing was done in both forward and reverse directions and compared to available sequences on GenBank using NCBI's BLAST online sequence analysis tool (Altschul et al. 1990). Species identification was accepted if the sequence matched vouchered GenBank specimens by at least $99 \%$. Analyses of stomach contents followed directions in Hyslop (1980): All prey items were quantified, and species abundance (number of individuals recovered from all stomachs) and frequency (percentage of stomachs that contained individuals of each species) were calculated.

\section{Results and discussion}

A total of 105 prey items were recovered from 44 stomachs, 21 of which were identified to species through morphological analysis in the field. The remaining 84 items 
Table 1 Fish species (grouped by family) recovered from lionfish stomachs in Belize

\begin{tabular}{|c|c|}
\hline $\begin{array}{l}\text { Family } \\
\quad \text { Species }\end{array}$ & Abundance \\
\hline Labridae & 70 \\
\hline Halichoeres socialis & 49 \\
\hline Scarus iseri & 15 \\
\hline Halichoeres bivittatus & 2 \\
\hline Sparisoma atomarium & 2 \\
\hline Sparisoma aurofrenatum & 1 \\
\hline Sparisoma viride & 1 \\
\hline Gobiidae & 19 \\
\hline Coryphopterus personatus & 18 \\
\hline Coryphopterus glaucofraenum & 1 \\
\hline Serranidae & 6 \\
\hline Serranus flaviventris & 4 \\
\hline Hypoplectrus puella & 2 \\
\hline Labrisomidae & 4 \\
\hline Labrisomus sp. & 3 \\
\hline Starksia occidentalis & 1 \\
\hline Bleniidae & 2 \\
\hline Parablennius marmoreus & 2 \\
\hline Apogonidae & 1 \\
\hline Apogon binotatus & 1 \\
\hline Monacanthidae & 1 \\
\hline Monacanthus ciliatus & 1 \\
\hline Pomacentridae & 1 \\
\hline Stegastes variabilis & 1 \\
\hline
\end{tabular}

Abundance refers to the total number of individuals found inside the 44 lionfish stomachs analyzed

were identified through sequencing of the cytochrome oxidase I mtDNA gene. Social wrasses represented $46 \%$ of the prey items investigated (Table 1) and were present in $18(41 \%)$ of the 44 stomachs with contents. Numbers of social wrasses in individual lionfish stomachs ranged from 1 to 18, with many stomachs containing 2-4 wrasses (Fig. 1b). While these figures might seem high, they are not unprecedented; during a study in the northern Caribbean, divers observed that a single lionfish consumed that 20 reef fishes in 30 min (Albins and Hixon 2008).

Our results demonstrate that the critically endangered social wrasse is the primary prey item of the invasive lionfish in Belize's inner barrier reef, both in numbers (Table 1) and in frequency. Similar studies conducted throughout the Caribbean indicate that wrasses and gobies (families Labridae and Gobiidae) are primary lionfish prey, especially species that, like the social wrasse, hover a few centimeters above the bottom, have elongated fusiform bodies, and range in size from 10 to $50 \mathrm{~mm}$ (Green and Côté 2014).
Although larger Caribbean fishes escape predation as adults, we found two mature female social wrasses inside one of the stomachs (Fig. 1b), potentially making this species even more vulnerable. Some Caribbean fish species, including Halichoeres burekae and Emblemariopsis randalli, are similar to the social wrasse in terms of geographic range, body size, behavior of hovering just above the reef, and threats of habitat degradation. The former is known from only three locations in the western Gulf of Mexico, and the latter is known only from Isla Cubagua off northeastern Venezuela. Given that both these locations now have invasive lionfish and also border oil and gas exploration activities, these species are potentially as threatened as the social wrasse.

The lionfish invasion of the Caribbean cannot be stopped; however, targeted removals have reduced lionfish numbers in many areas (Morris and Whitfield 2009; Albins and Hixon 2013; Côté et al. 2014). To date, these success stories are limited to the most popular dive destinations, and no targeted removal program is underway in Belize's inner barrier reef. Management efforts for the Pelican Cayes and other areas along the western and southern Caribbean should include targeted lionfish removal to alleviate predation on threatened species. In addition, with ongoing local development plans (Macintyre et al. 2009; UNESCO 2012), it is imperative to consider the risk of species extinctions and biodiversity loss when planning coastal development that could result in further habitat degradation. If invasive lionfish population controls are not initiated and habitat destruction is not stopped, the social wrasse and other small-range endemic fishes might be the first permanent casualties of the lionfish invasion.

Acknowledgments We thank C. Castillo, M. Halloran and D. Pitassy from the Smithsonian Institution for assistance in the field. We also thank B. Simison and A. Sellas for support at the Center of Comparative Genomics of the California Academy of Sciences. Financial support was provided by the California Academy of Sciences and the Smithsonian Institution. Specimens are housed in the ichthyology collection of the California Academy of Sciences. This is CCRE contribution number 971 .

Open Access This article is distributed under the terms of the Creative Commons Attribution 4.0 International License (http://creativecommons.org/licenses/by/4.0/), which permits unrestricted use, distribution, and reproduction in any medium, provided you give appropriate credit to the original author(s) and the source, provide a link to the Creative Commons license, and indicate if changes were made.

\section{References}

Albins MA (2012) Effects of invasive Pacific red lionfish Pterois volitans versus a native predator on Bahamian coral-reef fish communities. Biol Invas 15:29-43

Albins MA, Hixon MA (2008) Invasive Indo-Pacific lionfish Pterois volitans reduce recruitment of Atlantic coral-reef fishes. Mar Ecol Prog Ser 367:233-238 
Albins MA, Hixon MA (2013) Worst case scenario: potential longterm effects of invasive predatory lionfish (Pterois volitans) on Atlantic and Caribbean coral-reef communities. Env Biol Fishes 96:1151-1157

Altschul SF, Gish W, Miller W, Myers EW, Lipman DJ (1990) Basic local alignment search tool. J Mol Biol 215:403-410

Betancur-R R, Hines A, Acero A, Orti G, Wilbur AE, Freshwater DW (2011) Reconstructing the lionfish invasion: insights into Greater Caribbean biogeography. J Biogeogr 38:1281-1293

Clavero M, García-Berthou E (2005) Invasive species are a leading cause of animal extinctions. Trends Ecol Evol 20:110

Côté IM, Green SJ, Morris JA, Akins JL, Steinke D (2013) Diet richness of invasive Indo-Pacific lionfish revealed by DNA barcoding. Mar Ecol Prog Ser 472:249-256

Côté IM, Akins L, Underwood E, Curtis-Quick J, Green SJ (2014) Setting the record straight on invasive lionfish control: Culling works. PeerJ 2:e398v391

Green SJ, Côté IM (2014) Trait-based diet selection: prey behaviour and morphology predict vulnerability to predation in reef fish communities. J Anim Ecol 83:1451-1460

Hyslop EJ (1980) Stomach contents analysis-a review of methods and their application. J Fish Biol 17:411-429

Lobel PS, Rocha LA, Randall JE (2009) Color Phases and Distribution of the Western Atlantic Labrid Fish, Halichoeres socialis. Copeia 2009:171-174

Macintyre IG, Toscano MA, Feller IC, Faust MA (2009) Decimating mangrove forests for commercial development in the Pelican Cays, Belize: long-term ecological loss for short-term gain? Smith Contrib Mar Sci 38:281-290
Morris JA, Akins JL (2009) Feeding ecology of invasive lionfish (Pterois volitans) in the Bahamian archipelago. Env Biol Fishes 86:389-398

Morris JA, Whitfield PE (2009) Biology, ecology, control and management of the invasive Indo-Pacific lionfish: an updated integrated assessment Tech Mem NOS NCCOS 99. National Oceanic and Atmospheric Administration, Washington, DC

Pandolfi JM, Bradbury RH, Sala E, Hughes TP, Bjorndal KA, Cooke RG, McArdle D, McClenachan L, Newman MJH, Paredes G, Warner RR, Jackson JBC (2003) Global trajectories of the longterm decline of coral reef ecosystems. Science 301:955-958

Rocha LA, Choat JH, Craig MT (2010) Halichoeres socialis IUCN Red List of Threatened Species Version 20122, http://www. iucnredlist.org/details/187435/187430

UNESCO (2012) Decision 36COM 7A.15: Belize Barrier Reef Reserve System (Belize) (N 764): http://whc.unesco.org/en/ decisions $/ 4627$

Valdez-Moreno M, Quintal-Lizama C, Gómez-Lozano R, GarcíaRivas MDC (2012) Monitoring an Alien Invasion: DNA Barcoding and the Identification of Lionfish and Their Prey on Coral Reefs of the Mexican Caribbean. PLoS One 7:e36636

Weigt LA, Driskell AC, Baldwin CC, Ormos A (2012) DNA barcoding fishes. In: Kress WJ, Erickson DL (eds) DNA Barcodes: methods and protocols, pp109-126

Whitfield PE, Gardner T, Vives SP, Gilligan MR, Courtenay WR, Ray GC, Hare JA (2002) Biological invasion of the Indo-Pacific lionfish Pterois volitans along the Atlantic coast of North America. Mar Ecol Prog Ser 235:289-297 